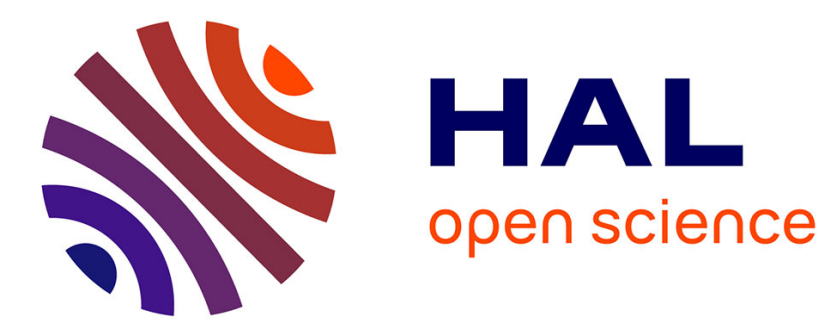

\title{
De la République de Constantin Pecqueur (1801-1887)
}

Samuel Hayat

\section{To cite this version:}

Samuel Hayat. De la République de Constantin Pecqueur (1801-1887). 2019, pp.1-3. 10.1080/23801883.2019.1571471 . hal-02358857

\section{HAL Id: hal-02358857 https://hal.univ-lille.fr/hal-02358857}

Submitted on 12 Nov 2019

HAL is a multi-disciplinary open access archive for the deposit and dissemination of scientific research documents, whether they are published or not. The documents may come from teaching and research institutions in France or abroad, or from public or private research centers.
L'archive ouverte pluridisciplinaire HAL, est destinée au dépôt et à la diffusion de documents scientifiques de niveau recherche, publiés ou non, émanant des établissements d'enseignement et de recherche français ou étrangers, des laboratoires publics ou privés. 
De la République de Constantin Pecqueur (1801-1887), edited by Clément Coste, Ludovic Frobert and Marie Lauricella, Presses universitaires de Franche-Comté, 2017, 464 p., $€ 25$ (paperback), ISBN: 9782848675824

The historiography of early nineteenth-century French socialism is currently ongoing a profound transformation. Paradoxically, in the past few decades, most of the progress in the knowledge of French early socialism has been made by English and American intellectual historians (such as Jonathan Beecher, Pamela Pilbeam, more recently Naomi Andrews), not by French ones. Intellectual history is by no means a well-developed field in French nineteenth-century history departments, and the rare exceptions have been more interested by liberalism than socialism. But since the beginning of the 2000s, a new generation of scholars, coming not only from history departments, but also from political science, philosophy, economy and law ones, has opened new research venues in the history of socialism. They have initiated investigations on new questions (socialist perspectives on technology, food, religion), reopened old discussions (socialist newspapers, the revolution of 1848, the First International), and helped rediscover long forgotten socialists, such as François Raspail and Constantin Pecqueur.

Constantin Pecqueur is the subject of the reviewed volume, published in the aftermath of a conference that took place in 2013, in a collection supervised by the philosopher Vincent Bourdeau and edited by the economist Ludovic Frobert and two scholars that were then his PhD students, Clément Coste and Marie Lauricella. Born in 1801 in Arleux, in the north of France, Constantin Pecqueur was part of a generation of thinkers and activists that did not personally experienced the French Revolution and discovered politics during the Restoration (1815-1830). It was a time of conspiracies and intellectual unrest that saw the burgeoning of the French liberal movement and the first conceptualisations of French socialism, under the pens of Saint-Simon and Fourier. After the revolution of July 1830 that gave birth to a liberal monarchy, Constantin Pecqueur, who had recently arrived in Paris, joined the newly founded Saint-Simonian church. He wrote several articles in the Globe, a former liberal newspaper that had been taken over by Saint-Simonians. This launched his intellectual career, first as a SaintSimonian, then as a Fourierist and later as an independent socialist thinker and writer. Between 1839 and 1844, he wrote eight books, laying the foundations of a distinctive socialist doctrine that advocated State property of the means of production and had strong moral and religious accents. During the revolution of 1848, he participated in the Luxembourg Commission, a working-class parliament led by the socialist minister Louis Blanc, influencing its projects of social reform. In 1849, he launched the newspaper Le Salut du Peuple, journal de la science sociale, but it was short-lived. After Louis-Napoléon Bonaparte's 1851 coup d'état, he stopped writing almost entirely, remaining a modest librarian at the National Assembly, but he kept a discreet influence among French working-class activists. This eventually led to his rediscovery as the pioneer of collectivism, shortly before his death in 1887, by the Internationalist and Communard Benoît Malon and his followers.

The book under review is the first recent attempt to give a full assessment of Constantin Pecqueur's thought. It alternates between chapters devoted to an aspect of Constantin Pecqueur's life and doctrine, and documents such as letters and unpublished texts. Two chapters inform the reader of the lesser-known years of Constantin Pecqueur's life: his early years, before 1830, documented by an extract from an unpublished biography by the late Jacques Thbaut, and his intellectual life after 1851, which is the subject of a chapter by Ludovic Frobert. The chapters by Philippe Régnier, Jonathan Beecher and Michel Bellet allow the reader to situate Constantin Pecqueur in the complex genealogies of modern socialism: Constantin Pecqueur was strongly influenced by Saint-Simon and Fourier, and his 
work was (for both intellectual and strategic reasons) appropriated by well connected socialists during the Third Republic. These three chapters convincingly picture him as a missing link between the well-known founders of French socialism in the 1820s-1840s and the French defenders of a republican collectivism in the 1880s-1900s. Political theorists, philosophers and historians of economic thought may be even more interested by the chapters that explore different aspects of Constantin Pecqueur's distinctive socialist doctrine. Ludovic Frobert, Vincent Bourdeau, Alain Clément, Clément Coste and Andrea Lanza's chapters are each devoted to one prominent part of Constantin Pecqueur's thought: his conception of political economy, his theory of property, the remedy to poverty and inequalities he advocated, his opinion on taxation and his plans for a reorganisation of credit. Finally, two chapters shed light on two overlooked parts of Constantin Pecqueur's thought: his defence of the emancipation of women, illustrated by Marie Lauricella through a chapter on his uncompleted project of writing a history of women; and his discreet contribution to the debate on direct government in 1849-51, studied by Anne-Sophie Chambost.

The book closes with a very useful bibliography of his published works, articles and unpublished manuscripts kept in the archives of the National Assembly. The whole constitutes an impressive piece of scholarship that should be useful to any scholar interested in the history of nineteenth-century socialism. Even though it discusses many aspects of the life and work of Constantin Pecqueur, it leaves a number of important questions unsolved, which may be the object of future research. First, most of the chapters in the book do not really make use of archival sources and as a result we do not know much about Constantin Pecqueur's life. In particular, it would have been helpful to be given some hypotheses about a troubling feature of his intellectual life: the fact that he wrote books only during five years, a surprisingly concentrated period for a man that lived until his $80 \mathrm{~s}$. He could have decided to observe a prudent silence during the Second Empire, but how did he react to the fall of the Empire, the return of the Republic, the Paris Commune? How come Benoît Malon, when he heard of Constantin Pecqueur in the 1880s, thought he was long dead?

Another set of questions concerns his doctrine. The authors of the book convincingly describe his attitude towards central dividing questions in the early socialist movement: the role of technological progress (Constantin Pecqueur was in favour of railroad development and he believed in the emancipatory power of technology but he was not a materialist), the relation to democracy (he was in favour of the Republic but he considered that it meant government for the people more than by the people), the role of morals and religion (he had a religious conception of socialism but he criticized traditional morality), the role of the State (he was a firm believer in its role in emancipating the masses, at least before 1848 but he believed in workers' associations). But do these different positions converge into a distinctive ideology? And if so, how could it be characterized? When Constantin Pecqueur's thought was rediscovered, at the end of the $19^{\text {th }}$ century, it was as the founder of a French version of collectivism that could be opposed both to the German communist thought of Karl Marx and Friedrich Engels and to the anarchism of Pierre-Joseph Proudhon that then constituted a reference for many French working-class activists. To what extent can it be said to be an accurate description of Constantin Pecqueur's ideology, if such an ideology existed? The book provides some answers, but nothing definitive, which may be due to the shortness of the introduction and the absence of conclusion. Future research should investigate more thoroughly Constantin Pecqueur's militant and intellectual activity after the revolution of 1848 , to assess the extent of his influence on working-class, republican and socialist activists and the prominent aspects of his doctrine once this defining moment was behind him. We can only hope that such research will be done in the very near future, as this edited volume shows 
without a doubt that Constantin Pecqueur was indeed an overlooked key actor in the history of French nineteenth-century socialism.

Samuel Hayat, CNRS, CERAPS 